\title{
ІСТОРІЯ НАУКИ
}

УДК 633.1:631.5

ФОРМУВАННЯ Б. М. РОЖЕСТВЕНСЬКИМ НАУКОВИХ ПІДХОДІВ ДО ТЕХНОЛОГІЙ ВИРОЩУВАННЯ ОСНОВНИХ ЗЕРНОВИХ КУЛЬТУР В УМОВАХ ЛІСОСТЕПУ УКРӒ̈НИ

I. В. Гребенюк, В. П. Петренкова

Інститут рослинництва ім. В. Я. Юр'єва НААН

В статті наведено результати багаторічних досліджень видатного вченого в галузі сільськогосподарської дослідної справи Бориса Миколайовича Рожественського, спрямованих на постановку методів вивчення впливу на урожай озимих та ярих культур обробітку грунту, строків сівби, дії добрив, порівняння ефективності варіантів дослідів та розробку основних елементів технології вирощування зернових культур в умовах Лісостепу України в діяльності Харківської обласної сільськогосподарської дослідної станції (нині Інститут рослинництва ім. В. Я. Юр'єва НААН).

Культура, технологія, урожайність, обробіток трунту, органічне добриво, строк сівби

Борис Миколайович Рожественський зробив значний особистий внесок у становлення та розвиток спочатку Харківського дослідного поля Центрального району, а згодом Харківської обласної сільськогосподарської дослідної станції (ХОСГДС).

Вченим обгрунтовано розробку програми наукової діяльності установ, завдяки якій дослідні станції успішно розвивались. Так, у 1912 році була опублікована наукова праця за редакцією Бориса Миколайовича «Проект программы опытного поля Харьковской опытной станции» [1]. Згодом під редакцією вченого виходили методичні рекомендації для господарств, які знаходились в Лісостепу України, а саме Харківській, Полтавській Курській та Воронезькій областей.

Земля, на якій вчений планував закладати досліди довгий час знаходилась в оренді у селян. Орендовані землі не удобрювались та були забур'янені. Борис Миколайович вирішив закладати на станції порівняльні досліди, з яких один - за місцевою технологією, другий - за технологією, розробленою вченим.

Розпочавши роботу на станції, вчений проаналізував можливі причини низького рівня урожайності основних сільськогосподарських культур, які вирощувались у той час в умовах Лісостепу України.

(C) І. В. Гребенюк, В. П. Петренкова. 2012.

ISSN 0582-5075. Селекція і насінництво. 2012. Випуск 102. 
У результаті проведеного Борисом Миколайовичем аналізу урожайності основних сільськогосподарських культур у господарствах Харківської губернії (нині Харківська область) отримані результати були не високими, в межах 0,82-1,18 т/га зернових колосових культур та 0,80 т/га круп'яних (гречки) (табл. 1).

Для порівняння Борис Миколайович також проаналізував середню урожайність зернових культур за ті ж роки в інших країнах, та виявив, що урожайність в країнах таких як Німеччина, Англія, Бельгія становила 1,89 т/га, 2,05 т/га, 2,10 т/га відповідно та була приблизно в два рази більшою, ніж в Україні [2, С. 1-2].

Таблиця 1

Урожайність основних сільськогосподарських культур в господарствах Харківської губернії, 1906-1915 pp.

\begin{tabular}{|l|c|c|}
\hline \multirow{2}{*}{ Культура } & \multicolumn{2}{|c|}{ Урожайність } \\
\cline { 2 - 3 } & пуди/дес. & перерахунок, т/га $^{*}$ \\
\hline Жито & 65 & 1,06 \\
\hline Пшениця озима & 72 & 1,18 \\
\hline Пшениця яра & 50 & 0,82 \\
\hline Овес & 64 & 1,05 \\
\hline Ячмінь & 54 & 0,88 \\
\hline Гречка & 49 & 0,80 \\
\hline
\end{tabular}

*1 пуд - 16,38 кг, 1 десятина - 1,0925 га

У зв'язку з цим вчений, як директор Харківської обласної сільськогосподарської дослідної станції та завідувач відділом рільництва, в плані практичних досягнень станції поставив задачу отримати такі ж високі врожаї озимих і ярих культур, як і в інших країнах Європи.

Перш за все, за думкою Б. М. Рожественського, для збільшення урожайності озимих зернових культур важливо було враховувати в технології вирощування строк основного обробітку грунту під чорний пар. Вчений вважав, що найкращим попередником для озимих культур в зоні Лісостепу були чисті та зайняті пари. Для підтвердження думки вчений закладає дослід для вивчення впливу строку підйому пару на культурі жита озимого $[2$, C. 3-4].

За технологією вирощування жита озимого в місцевих господарствах оранку проводили на глибину 22 см (табл. 2).

Борис Миколайович за результатами проведеного досліду встановив, що на чорноземах станції збільшення глибини оранки не приводить до збільшення урожайності та рекомендував проводити основний обробіток ранніх парів, як попередника жита озимого, навесні, не пізніше першої половини травня. Пізній пар, піднятий в середині липня, знижував урожайність жита озимого на 0,6 т/га. 
Вплив строку підйому пару на урожайність жита озимого, 1913-1917 pp.

(в перерахунку на т/га)

\begin{tabular}{|c|c|c|c|}
\hline \multicolumn{5}{|c|}{ Глибина оранки, см } \\
\hline \multicolumn{3}{|c|}{ у травні } & 9 \\
\hline 9 & 22 & 9 \\
\hline \multicolumn{5}{|c|}{ Урожайність, т/га липні } \\
\hline 2,41 & 2,34 & 1,83 & 1,80 \\
\hline
\end{tabular}

Під керівництвом вченого проводились досліди з вивчення впливу глибини оранки під такі культури, як ячмінь ярий, просо, кукурудза [2, С. 5-6].

Проведені досліди на ярих культурах підтвердили висновок вченого про проведення основного обробітку грунту під ці культури на глибину 9 см (табл. 3).

Різниця в урожайності озимих зернових, ранніх зернових та пізніх зернових за глибиною оранки не спостерігалась. Борис Миколайович рекомендував для місцевих господарств проводити оранку на глибину 9-13 см.

Таблиця 3

Вплив глибини оранки на урожайність зернових культур, 1913-1917 pp.

(в перерахунку на т/га)

\begin{tabular}{|l|c|c|c|}
\hline \multirow{2}{*}{\multicolumn{1}{|c|}{ Культура }} & \multicolumn{3}{|c|}{ Глибина оранки } \\
\cline { 2 - 4 } & $9 \mathrm{~cm}$ & $16 \mathrm{~cm}$ & $22 \mathrm{~cm}$ \\
\hline Жито озиме & 2,4 & 2,4 & 2,3 \\
\hline Ячмінь ярий & 1,5 & 1,4 & 1,4 \\
\hline Просо & - & 2,5 & 2,5 \\
\hline Кукурудза & 3,1 & 3,1 & 3,0 \\
\hline
\end{tabular}

Коли Борис Миколайович закладав досліди на станції, в місцевих технологіях вирощування озимих культур головним засобом підвищення урожайності вважалося тільки проведення основного обробітку грунту. Але, вчений встановив, працюючи ще на посаді керівника мережі колективних дослідів Катеринославської губернії, що внесення добрив на чорноземах також збільшує урожайність озимих культур. Встановлено, що частка добрив у формуванні врожаю становить 30-40\%, що значно вище, ніж частка обробітку грунту.

Протягом 1913-1916 рр. на Харківській дослідній станції під керівництвом вченого вивчався вплив внесення добрив на урожайність основних сільськогосподарських культур.

Як приклад, для порівняння урожайності жита озимого одне поле обробляли згідно технології місцевого господарства (схема № 1 - оранка на глибину 22 см, без добрив, а друге - за програмою Бориса Миколайовича (схема № 2 - оранка на глибину 9-13 см, внесення гною 19,7 тонн). 
Згідно з результатами чотирьохрічних досліджень урожайність жита озимого на полі місцевого господарства та на дослідному полі Харківської станції, де вирощували за технологією місцевого господарства була однаковою і становила 1,5 т/га та 1,6 т/га відповідно. А за вирощування на удобреному фоні, згідно схеми № 2, урожайність жита озимого була вдвічі більша $-3,1$ т/га. Згідно цих даних, Борис Миколайович рекомендував для отримання більш високих врожаїв проводити основний обробіток грунту на глибині 9-13 см та вносити органічні добрива в межах 20 т/га. Але на той час у місцевих господарствах не вистачало гною, тому Борис Миколайович закладав досліди з вивчення можливості його заміни повної або часткової на мінеральні добрива. В ході досліджень 31913 року по 1917 рік вчений встановив, що для чорноземів найбільш придатним для використання є суперфосфат.

Серед питань технології вирощування озимих культур особливе місце займало вивчення впливу строків сівби на урожайність, досліди з цього напряму Борис Миколайович проводив ще з початку функціонування дослідної станції [2, С. 9-16].

Дослідження показали, що процес росту та розвитку озимих культур і їх продуктивність значною мірою залежали від погодних умов осені в післяпосівний період і весни на початку поновлення вегетації. Також було виявлено відмінності в урожайності за реакцією окремих сортів пшениці озимої на строки сівби (табл. 4).

Таблиця 4

Вплив строків сівби озимих культур на урожайність, 1914-1917 pp.

(в перерахунку на т/га)

\begin{tabular}{|l|c|c|c|c|c|c|c|}
\hline \multirow{3}{*}{ Культура } & \multicolumn{7}{|c|}{ Строк сівби } \\
\cline { 2 - 8 } & 05.07 & 15.07 & 05.08 & 15.08 & 25.08 & 05.09 & 15.09 \\
\cline { 2 - 8 } & \multicolumn{7}{|c|}{ Урожайність, т/га } \\
\hline Жито озиме & 1,3 & 2,3 & $\mathbf{2 , 5}$ & 2,3 & 2,3 & 1,6 & 1,2 \\
\hline Пшениця озима & 1,9 & 2,5 & 2,6 & $\mathbf{2 , 8}$ & 2,6 & 2,1 & 1,4 \\
\hline
\end{tabular}

За показниками урожайності оптимальними строками сівби для жита озимого виявився період після п'ятого серпня, а для пшениці озимої - після 15 серпня. Для місцевих господарств вчений рекомендував висівати жито озиме в першій декаді серпня, а пшеницю озиму - в другій декаді серпня для отримання високих врожаїв. У 1914-1917 рр. серед варіантів вивчення кращого періоду висіву озимих культур був варіант надраннього строку сівби - 5 липня, та згодом надто ранні строки висіву були визнані як недоцільні через низький рівень урожайності.

Практично у всіх дослідах оптимальний строк сівби пшениці озимої знаходився в межах третьої декади серпня - першої декади вересня. Надто пізній посів (після вересня) був недоцільним, оскільки урожай пшениці озимої в цьо- 
му випадку був на рівні ярої. Жито озиме виявилось більш пластичним до строку сівби, ніж пшениця озима, і тому його доцільно було висівати в разі вимушеного запізнення з проведенням сівби пшениці озимої [4].

Під керівництвом Бориса Миколайовича та співробітниками відділу рільництва вивчались також різні способи висіву пшениці озимої: звичайний рядковий, вузькорядковий, перехресний, широкорядний 3 міжряддями 25 см. У результаті проведених досліджень встановлено, що вузькорядний спосіб забезпечував прибавку 0,11 , а перехресний - 0,14 т/га в порівнянні зі звичайним. Широкорядний спосіб сівби давав ефект лише на удобрених фонах і був доцільним при розмноженні дефіцитного насіння. Згодом було встановлено, що найбільш обгрунтованою нормою висіву цієї культури по угноєному чистому пару було 2-3 млн. схожого насіння на 1 га, а на неудобреному фоні 3-4 млн. Після кукурудзи доцільно висівати 5 млн. насіння незалежно від строків сівби і стану удобреності грунту. Методичні рекомендації з вирощування пшениці озимої, які обгрунтовані Борисом Миколайовичем 3 деякими змінами в строках сівби даної культури і до сьогоднішнього дня використовуються при вирощуванні пшениці озимої.

Також за керівництва Бориса Миколайовича відділом рільництва вивчався вплив строків сівби на урожайність ярих культур, які вирощували на Харківській обласній сільськогосподарській дослідній станції [5] (табл. 5).

Таблиця 5

Вплив строків сівби ранніх ярових культур на урожайність, середнє за 1913-1917 pp. (в перерахунку на т/га)

\begin{tabular}{|l|c|c|c|c|c|c|}
\hline \multirow{2}{*}{ Культура } & \multicolumn{7}{|c|}{ Строк сівби } \\
\cline { 2 - 7 } & 01.04 & 10.04 & 20.04 & 01.05 & 10.05 & 20.05 \\
\hline Ячмінь & 1,2 & 1,0 & 0,6 & 0,3 & 0,4 & - \\
\hline Пшеница яра & 1,3 & 1,0 & 0,7 & 0,5 & 0,4 & 0,3 \\
\hline Овес & 1,9 & 2,0 & 1,7 & 1,3 & 1,0 & 0,5 \\
\hline
\end{tabular}

За даними результатів проведених досліджень визначено, що сівбу ранніх ярих культур необхідно було проводити в максимально ранні та стислі строки при настанні фізичної стиглості грунту. Запізнення з сівбою призводило до значного зниження урожайності культур.

У методичних рекомендаціях для місцевих господарств Борис Миколайович звертав увагу на те, що найбільш вимогливими до строків висіву були пшениця та ячмінь ярі. Так, наприклад, висів ячменю ярого в першій декаді квітня забезпечував урожайність в межах 1,2 т/га, а в третій - урожайність зменшувалась і становила 0,6 т/га. Пізній висів пшениці ярої (20 квітня) забезпечував урожайність на рівні 0,7 т/га, що майже вдвічі менше, ніж при ранньому висіві $(1,3$ т/га). Урожайність вівса знижувалась на 0,2 т/га у третій декаді квітня. Встановлено також, що висів ранніх ярих культур у травні місяці виявився економічно недоцільним. 
При вивченні впливу строку сівби на урожайність пізніх ярових культур (гречка та просо) встановлено оптимальні строки для висіву гречки протягом першої-другої декади травня, для висіву проса - друга декада квітня (табл. 6).

Таблиця 6

Вплив строків висіву на урожайність пізніх ярих культур, 1913-1916 рр.

(в перерахунку на т/га)

\begin{tabular}{|c|c|c|c|c|c|c|c|c|c|}
\hline \multirow{4}{*}{ Культура } & \multicolumn{9}{|c|}{ Строк сівби } \\
\hline & \multicolumn{3}{|c|}{ квітень } & \multicolumn{3}{|c|}{ травень } & \multicolumn{3}{|c|}{ червень } \\
\hline & 01 & 10 & 20 & 01 & 10 & 20 & 01 & 10 & 20 \\
\hline & \multicolumn{9}{|c|}{ Урожайність, т/га } \\
\hline Гречка & & 1,5 & 1,4 & 2,0 & 2,1 & 2,2 & 1,9 & 1,8 & 1,3 \\
\hline Просо & 1,8 & 2,2 & 2,2 & 2,0 & 2,3 & 2,2 & 2,3 & 1,8 & 0,1 \\
\hline
\end{tabular}

При аналізі результатів дослідження Борис Миколайович встановив, що ранні строки сівби гречки знижували урожайність цієї культури, посіви могли загинути від заморозків. Ранні посіви проса були дуже забур'янені, що знижувало рівень урожайності цієї культури.

Також вченим вивчались протягом 1913, 1915, 1917 років строки сівби цукрового буряку. За отриманими результатами було встановлено термін висіву - протягом першої декади квітня. Для соняшнику встановлено оптимальним строком сівби перша декада квітня.

Серед архівних документів ЦДАВО України знайдено доповідь Бориса Миколайовича стосовно вирішення проблеми підвищення врожайності [6]. На думку вченого, основними прийомами підвищення врожайності сільськогосподарських культур є підбір сорту, ефективність обробітку грунту, внесення органічного та мінерального добрива, дотримання сівозмін, підбір кращого попередника культур та низький рівень забур'яненості.

Аналізуючи грунтово-кліматичні та економічні умови Лісостепу, вчений дійшов висновку, що за сприятливих грунтово-кліматичних умов та недостатньої земельної площі, невеликого капіталу одним 3 найкращих прийомів підвищення урожайності буде введення нових сортів, але для цього необхідно продумувати організацію насінництва та насіннєзнавства.

Для цього необхідно замінити попередники під основні сільськогосподарські культури і висівати по просапних культурах та травах, а не по ярих зернових культурах.

Відносно обробітку грунту, економічно вигідно використовувати зайняті пари на відміну від чистого пару. Внесення 19 тонн органічного добрива (гною) давала прибавку урожайності як на перший рік внесення, так i на другий (табл. 7).

На думку вченого, введення нових сортів сприятиме збільшенню урожайності на 0,3 т/га, застосування мінеральних добрив - 0,3-0,4 т/га, органічних добрив - 0,5-0,6 т/га, вибір кращих попередників - 0,3-0,4 т/га [7]. 
Вплив внесення органічного добрива на урожайність культур, 1928 рік

(перерахунок в т/га)

\begin{tabular}{|l|c|l|c|}
\hline \multicolumn{1}{|c|}{ Культура } & $\begin{array}{c}\text { Урожайність, } \\
\text { т/га 1 рік }\end{array}$ & \multicolumn{1}{|c|}{ Культура } & $\begin{array}{c}\text { Урожайність, т/га } \\
2 \text { рік (післядія) }\end{array}$ \\
\hline Жито озиме & 0,6 & Пшениця яра & 0,3 \\
\hline Пшениця озима & 0,5 & Овес & 0,06 \\
\hline Буряк цукровий & 7,7 & Ячмінь & 0,3 \\
\hline Картопля & 2,4 & Буряк цукровий & 3,0 \\
\hline
\end{tabular}

Дослідження з круп'яними культурами у відділі рільництва були сконцентровані, головним чином, на агротехніці їх сівби. Відповідні досліди були розпочаті у 1913 році і час від часу повторювались у подальшому. Багаторічні дослідження дали змогу зробити певні узагальнення.

Так, у науковій спадщині вченого знаходиться стаття «Про просо», яка змістовно розкриває способи та строки сівби проса. За даними вченого урожайність проса в досліді з різними строками сівби ярих культур у середньому за чотири роки (1913-1916 рр.) була в межах 0,1-2,1 т/га, навіть у ті строки сівби, коли ярі культури вже не здатні були сформувати урожай зерна (табл. 8).

Таблиця 8

Вплив строків сівби на урожайність ярих культур, 1913-1916 pp.

\begin{tabular}{|l|c|c|c|c|c|c|c|c|c|c|c|}
\hline \multirow{2}{*}{ Культура } & \multicolumn{10}{|c|}{ Строки сівби } \\
\cline { 2 - 11 } & 13.04 & 23.04 & 03.05 & 13.05 & 23.05 & 03.06 & 13.07 & 23.07 & 03.08 \\
\hline $\begin{array}{l}\text { Пшениця } \\
\text { яра }\end{array}$ & 0,1 & 0,1 & 0,06 & 0,04 & 0,03 & 0,02 & 0,01 & - & - \\
\hline Ячмінь & 0,1 & 0,1 & 0,06 & 0,03 & 0,04 & - & - & - & - \\
\hline Овес & 0,2 & 0,2 & 0,2 & 0,1 & 0,08 & 0,01 & 0,01 & - & - \\
\hline Просо & 0,2 & 0,2 & 0,2 & 0,2 & 0,2 & 0,2 & 0,2 & 0,15 & 0,1 \\
\hline
\end{tabular}

На забур'янених полях гречку і просо краще було сіяти широкорядним способом. На чистих полях і при більш пізніх строках сівби перевага надавалась звичайному рядковому способу. Кращою нормою висіву гречки при звичайному рядковому висіві 79 кг/га, для висіву з міжряддями 25 і 35 см - 60 кг/га, а для висіву з міжряддями 45 см - 45 кг/га.

Висновки. Протягом 20-річної науково-дослідної роботи на Харківській обласній дослідній станції Борисом Миколайовичем надруковано понад 60 наукових праць. Борис Миколайович пропагував досягнення дослідної справи на численних конференціях, з'їздах, нарадах.

Напружена наукова праця, якій вчений віддався сповна, підірвала його здоров'я. У шістдесят дев'ять років він пішов з життя. Але справа, започаткована Б. М. Рожественським на високому науково-методичному рівні, має 
своє продовження в тематиках лабораторій рослинництва та сортовивчення та сектору технології захисту рослин Інституту рослинництва ім. В. Я. Юр'єва НААН. Для наукового забезпечення ефективного проведення комплексу польових робіт у східній частині Лісостепу України, при складанні методичних рекомендацій по вирощуванню сільськогосподарських культур доцільно використовувати базисні методичні розробки академіка Б. М. Рожественського, які на теперішній час не втратили своєї актуальності.

\section{Список використаних джерел}

1. Рожественский Б. Н. Проект программы опытного поля Харьковской опытной станции / Б. Н. Рожественский // Труды Харьковской сельскохозяйственной опытной станции. - Х., 1912. - Вып. 1. - 54 с.

2. Рожественский Б. Н. Главнейшие выводы полевых опытов 1913-1917 / Б. Н. Рожественский, Э. О. Заславский. - Х., 1922. - 74 с.

3. Рожественский Б. Н. Краткий сводный отчет по полевым опытам за 1912-1925 гг. / Б. Н. Рожественский, П. Г. Найдин. - Х., 1926. - Вып. 23. - C. 22- 26.

4. Зуза В. С. Результати досліджень інституту з питань землеробства впродовж сторіччя (1908-2008 pр.) / В. С. Зуза // Агротехнологія польових культур : зб. наук. праць. - Х., 2009. - с. 53-56.

5. Рожественский Б. Н. Краткий отчет о работах опытного поля Харьковской опытной станции за 1912-1914 гг. / Б. Н. Рожественский. - Х., 1915. - 47 с.

6. Центральний державний архів вищих органів влади та управління України (ЦДАВО), ф. 27, оп. 9, спр. 509, арк. 65-73.

7. Рожественский Б. Н. Обзор результатов полевых опытов отдела полеводства Харьковской областной с.-х. опытной станции / Б. Н. Рожественский - X., 1948. - C. 24-53.

В статье приведены результаты многолетних исследований выдающегося ученого в области сельскохозяйственного опытного дела Бориса Николаевича Рожественского, направленных на постановку методов изучения влияния на урожай озимых и яровых культур обработки почвы, сроков посева, действия удобрений, сравнения эффективности вариантов исследований и разработку основных элементов технологии выращивания зерновых культур в условиях Лесостепи Украины в деятельности Харьковской областной сельскохозяйственной опытной станции (ныне Институт растениеводства им. В. Я. Юрьева НААН).

The paper presents the results of years of research, an outstanding scientist in the field of agricultural research affairs Boris Nikolayevich Rozhdestvensky aimed at setting methods for studying the impact on yield of winter and spring crops tillage, sowing, fertilizer action, comparing the effectiveness of research and development options for the basic elements of technology growing crops under steppes of Ukraine in the Kharkiv Regional agricultural Experimental Station (now the Institute of plant production nd. a V. Ya. Yuryev NAAS). 